\title{
The Development of Teaching Materials Writing Biography Text Based on Mind Map
}

\author{
Ernanda Ariyatna \\ Postgraduate Program of Indonesian Language and Literature Education \\ Universitas Negeri Medan \\ Medan, Indonesia \\ Corresponding email: ernanda.ariyatna@gmail.com \\ Abdurrahman Adisaputera \\ Postgraduate Program of Indonesian Language and Literature Education \\ Universitas Negeri Medan \\ Medan, Indonesia \\ Isda Pramuniati \\ Postgraduate Program of Indonesian Language and Literature Education \\ Universitas Negeri Medan \\ Medan, Indonesia
}

\begin{abstract}
Teaching materials is a device that occupies the most important position in learning that is used to facilitate the course of learning activities. Teaching materials allow students to learn a competence coherently and systematically so that the accumulative able to master all the competencies as a whole and integrated. This study aims to produce teaching materials writing biography text based on mind map in the form of module. This is a Research and Development ( $R$ \& D) method with ADDIE development model. The subjects of this study are 3 students for individual trials, 9 students for small group trials, and 32 students for limited field trials. Product quality assessment using questionnaire and analyzed using qualitative descriptive analysis technique. Based on data analysis, the overall assessment of module material is at very good criteria. The content feasibility assessment has an average percentage of $85 \%$, the presentation feasibility assessment has an average percentage of $98.87 \%$ and the language feasibility assessment has an average percentage of $87.5 \%$, while overall the design assessments are at very good criteria with an average percentage of $88.3 \%$. This means that teaching materials writing biography text based on mind map is feasible and very good to be implemented in the learning process.
\end{abstract}

Keywords-development; teaching materials; writing; biography text; mind map

\section{INTRODUCTION}

Indonesian language learning is learning based on text. Based on this learning, students are faced with the fact that students must have a lot of teaching materials to support learning in school. To meet these demands, teachers must prepare themselves to arrange teaching materials in order to increase students' knowledge and learning experience. But in fact many teachers who have not been able to arrange the teaching materials as a companion teaching materials textbooks in schools. Whereas the required competence of teachers is "developing curriculum related to the field of development that is supported," and "conducting educational development activities," for pedagogical competence as well as "developing creative learning materials" and "utilizing information and communication technology to communicate and develop themselves "for professional competence. Based on the demands as well as these obligations, one of the teachers must be able to prepare innovative teaching materials that are in accordance with the curriculum, the development of student needs, as well as the development of technology and information [1].

The presence of companion teaching materials is considered necessary due to the lack of textbooks. The presence of textbooks as meeting the needs of students in learning does not always provide a significant contribution in the learning process. Educational experts have a negative attitude or antipathy over the presence of textbooks in the world of education based on the fact that textbooks pay less attention to individual student differences because target students are considered homogeneous, the context and teaching materials contained in textbooks are often incompatible with the conditions and environment of students target [2]. Seeing the conditions that occur, it is felt necessary to do this development research to produce a teaching materials that can enrich the insight of students in the form of modules. Modules serve as the result of product development because the module is considered as a resource that has many advantages. Modules are a structured, coherent and explicit, 
formal learning experience of learning outcomes and assessment criteria. Modules can help learners build what they learn, understand, and facilitate to participate actively in the process [3].

The development of teaching materials focused on developing teaching materials for biograhy text. The focus of the development is based on the results of the observation to the students who claim that this learning is felt the most difficult to learn. Learning to write biograhy text will be an exciting learning experience if the modules produced will be based on mind maps. Mind mapping is a strategy that can be used to encourage 'deep' learning not just 'skin'. 'In-depth' learning is intrinsically motivated, meaning students try to find out the meaning of their work and understand the context of new ideas and concepts. Students who learn only 'skin' tend to be motivated from the outside and tend to memorize without understanding [4]. Mind mapping activities require students to actively engage in their learning, which often connects prior knowledge with new information. Mind maps help students learn the information by forcing them to organize it and add pictures and colors [5]. The mind map is one of the best methods to optimize learning ability and understanding of how complex structural elements are connected [6].

Based on the above, it is necessary to conduct research on developing teaching materials writing biography text that produce a module of writring biography text based on mind map to be implemented in learning. This research is conducted to improve the quality of education in terms of the learning process at vocational high school 2 Medan.

\section{METHOD}

The method used in this research is research and development ( $\mathrm{R} \& \mathrm{D})$ method with development model of ADDIE (Analyze, Design, Development, Implementation, Evaluation). This model is structured programmatically with sequences of systematic activities in the effort to solve learning problems related to learning resources that match the needs and characteristics of learners. The ADDIE model consists of five steps: (1) analysis, (2) design, (3) development, (4) implementation, and (5) (evaluation) [7].

\section{RESULTS}

A. Analysis

Analysis aims to analyze the needs of teaching materials needed by teachers and students on the learning process. The needs analysis is used to collect information about teaching materials such as what is needed by teachers and students in learning biograhy text. Analysis of the needs for teaching materials is done by distributing questionnaires to all Indonesian teachers and 32 students. The result is all of students and teachers requires teaching materials based on mind map in the form of module.

\section{B. Design}

Design is intended to prepare all that is needed in the development of teaching materials so that teaching materials developed can support learning in school. Design is a step for create an outline of the material, preparing reference books to be used for the collection of information, materials, images, and examples for module preparation, and specify module specification or module format.

\section{Development \\ 1. Development of Teaching Materials}

Development is intended as the realization of the design that has been made. At this step a product produced a teaching material as a result of the development of teaching materials. The product produced in accordance with the design that has been made is a creative and dynamic module, the module of writing biograhy text based on mind map. This module has many components that make this module rich in information and practice that will increase knowledge.

\section{Assessment of the feasibility of Module (Validation Module) by Expert}

Assessment of the feasibility of module (validation module) is carried out by two experts, namely the materials experts and design experts, each of them consists of 2 experts qualified in their fields. Assessment of the feasibility module of by materials experts include three assessment, namely content feasibility, presentation feasibility, and language feasibility. Meanwhile, the assessment of the feasibility of module by design experts include assessment design module as a whole [8]. Based on data analysis, the overall assessment of module material is at very good criteria. The content feasibility assessment has an average percentage of $85 \%$, the presentation feasibility assessment has an average percentage of $98.87 \%$ and the language feasibility assessment has an average percentage of $87.5 \%$, while overall the design assessments are at very good criteria with an average percentage of $88.3 \%$. This indicates that the module is valid and feasible to be tested on students.

\section{The Responses of Indonesian Teachers to the Module}

The module of writing biograhy text based on mind map that have been declared eligible by materials experts and design experts shared with 8 Indonesian teacher to determine the responses of teachers to the module. The results of the responses of Indonesian teachers to the module has very good criteria with average percentage of $92,5 \%$, it can be concluded that in view of the average percentage of the results responses of 8 Indonesian teachers, the module of writing biograhy text based on mind map has a very good criteria. It shows that the module is very good to be tested on students of vocational high school 2 Medan. The module is expected to be a companion instructional materials to facilitate the course of the learning process in school.

\section{Implementation \\ The Responses of Students to the module on Individual, Small Group, and Field Limited Trial}

The module of writing biography text based mind map that have been declared eligible by materials experts and design experts and have very good results of responses from 
Indonesian teachers then tested at vocational high school 2 Medan on individual, small group, and field limited trial to determine the responses of the students as the subjects trial to the module. The assessment responses from individual trial students are at very good criteria with average percentage of $85.3 \%$, small group trial assessments are at very good criteria with average percentage of $88.7 \%$ and a limited field trial assessment is in the criteria very good with average percentage of $93.5 \%$.

Based on the results of the responses of students as the subjects trial of the module above, it can be concluded that the responses of students to the individual trial, small group trial, and limited field trial are in very good criteria. It shows that the module of writing biograhy based on mind map as the result of the development of teaching materials has been feasible and very good to be implemented in the learning activity at vocational high school 2 Medan on the related materials to support the improvement of learning quality in school.

\section{E. Evaluation}

Evaluation has actually been done since the early steps of development. Evaluation take place at every steps to continue to see the quality of products to be produced. At this step the final product in the form of biograhy text based on mind map module has been completed and can be used later in the learning process for a larger scope. Module is eligible for students of vocational high school 2 Medan.

\section{CONCLUSIONS}

The development of teaching material writing biograhy text based on mind map that generate a module has gone through several steps of assessment (validation) and responses. Based on the results of the assessment (validation) by the materials and design experts, as well as the responses of teachers and the responses of students as the subjects trial, it can be concluded that this study has produced a product of teaching materials in the form of writing biograhy text based on mind map module that is feasible and good for implemented at vocational high school 2 Medan as a companion teaching materials and supporting the continuity of learning activities and to improve the quality of learning in school.

\section{REFERENCES}

[1] Law on Teachers and Lecturers, "Law on Teachers and Lecturers No. 14", Jakarta, 2005.

[2] M. Muslich, “Textbook Writing”, Jogjakarta: Ar-Ruzz Media, 2016.

[3] Rufii, "Developing Module on Constructivist Learning Strategies to Promote Students' Independence and Performance", Vol. 7, No. 1, 2015, pp. 18-28.

[4] Tony Buzan and Barry Buzan, "Memahami Peta Pikiran”. Batam: BBC, 2004.

[5] Brett D. Jones, Chloe Ruff, Jennifer Dee Snyder, Britta Petrich, Chelsea Koonce, "The Effects of Mind Mapping Activities on Students' Motivation”, Vol. 6, No. 1, 2012, Article 5.

[6] Marcus Ingemann, "The Power of Mind Mapping”, Fortunewell, Buzan Organisation.

[7] M. Tegeh, N. Jampel, K. Pudjawan, "Model Penelitian Pengembangan". Yogyakarta: Graha Science, 2014.

[8] Badan Standar Nasional Pendidikan. "Standar Penilaian Bahan Ajar". Jakarta: BSNP, 2007. 